\title{
PERMODELAN PENGEKANGAN KOLOM PADA BETON MUTU NORMAL DENGAN METODE ELEMEN HINGGA 3-D
}

\author{
Ridho Saleh Silaban ${ }^{1}$, Darmansyah Tjitradi ${ }^{2}$, Syahril Taufik ${ }^{3}$ \\ ${ }^{1}$ Mahasiswa Pasca Sarjana Teknik Sipil Universitas Lambung Mangkurat \\ ${ }^{2,3}$ Dosen Fakultas Teknik Universitas Lambung Mangkurat \\ ${ }^{1}$ ridho.saleh.silaban@gmail.com
}

\begin{abstract}
ABSTRAK
Kolom merupakan element kritis pada struktur bangunan, kegagalan kolom akan berakibat langsung pada runtuhnya komponen struktur lain yang berhubungan. Kolom harus memiliki kekuatan, stabilitas dan daktilitas. Dalam meningkatkan kapasitas dan daktilitas kolom dengan memberikan pengekangan (confinement), untuk melindungi element beton agar tidak pecah akibat pengaruh tekanan yang bekerja. Menganalisis kemampuan beban aksial ultimit, pola distribusi tegangan-regangan dan pola retak pada element beton dan daktilitas kolom. Pengujian beberapa model dan variasi jarak pengekangan pada kolom pendek mutu beton normal dengan tulangan longitudinal baja ulir dan tulangan transversal baja carbon. Kolom dianalisis menggunakan metode Finite Element Analisis (FEA) dengan bantuan Aplikasi ANSYS 3-D full scale, dengan material properties untuk beton menggunakan SOLID65 dan tulangan baja menggunakan LINK8 serta loading plat SOLID45. Jenis tumpuan yang dipakai adalah sendi-sendi dengan pemberian pembebanan bertahap (loadstep) aksial arah sentris. Pengaruh model pengekang dan variasi jarak pengekangan terhadap nilai beban aksial ultimit kolom untuk seluruh model relatif kecil dengan rasio perbandingan sebesar 1,079, sedangkan untuk rasio perbandingan nilai aksial deformasi sebesar 1,496. Pola distribusi tegangan dan regangan pada saat yielding menyebar diseluruh area kolom namun pada saat mencapai ultimit distribusi terkonsentrasi pada area tumpuan. Retak pertama dominan terjadi pada area tumpuan dan pada umumnya terjadi pada lapisan selimut beton, pada kondisi ultimit retakan sudah terjadi merata diseluruh area kolom. Rasio perbandingan nilai daktilitas untuk semua model kolom dan jarak pengekangan relatif cukup besar dengan nilai rasio 1,523
\end{abstract}

Kata kunci: beton mutu normal, daktilitas, FEA, full scale, kolom, pengekangan

\section{ABSTRACT}

The column is a critical element in the building structure, the failure of the column will directly result in the collapse of other related structural components. The column must have strength, stability and ductility. In increasing the capacity and ductility of the column by providing confinement, to protect concrete elements from breaking due to the influence of the working pressure. Analyzing ultimate axial load capability, stressstrain distribution patterns and crack patterns in concrete elements and column ductility. Tests of several models and variations of the restraint distance in short columns of normal concrete quality with longitudinal reinforcement of steel steels and carbon steel transversal reinforcement. The columns were analyzed using the Finite Element Analysis (FEA) method with the help of a full scale ANSYS 3-D application, with material properties for concrete using SOLID65 and steel reinforcement using LINK8 and SOLID45 loading plates. The type of pedestal used is the joints with axial loading (axial loadstep) centric direction. The effect of the restraint model and the variation of the restraint distance to the value of the column ultimate axial load for the 
whole model is relatively small with a ratio of 1.079, while for the ratio of the axial deformation ratio of 1.496. The pattern of stress and strain distribution when yielding spreads throughout the column area but when it reaches the ultimate distribution the concentration is concentrated in the support area. The first dominant crack occurs in the pedestal area and generally occurs in the concrete blanket layer, in the ultimate condition cracks have occurred evenly throughout the column area. The ratio of the ratio of ductility values for all column models and the restraint distance is relatively large with a ratio value of 1.523

Keywords: column, ductility, FEA, full scale, normal quality concrete, restraints

\section{PENDAHULUAN}

Dalam SNI 03-2847-2002 struktur bangunan dirancang bersifat daktail, kolom yang dirancang harus memiliki kekuatan, stabilitas dan daktilitas. Daktilitas aksial adalah kemampuan struktur untuk berdeformasi aksial secara inelastis termasuk lendutan terbesar dan menyerap energi tanpa mengalami reduksi kekuatan secara signifikan sebelum mencapai keruntuhan. Rasio antara deformasi maksimum struktur dengan deformasi yang terjadi saat mengalami yielding leleh.

Untuk meningkatkan daktilitas kolom yang menggunakan bahan beton adalah dengan mengontrol secara khusus desain penulangannya yaitu memberikan model pengekangan (confinement). Park dan Paulay (1975), mengatakan sengkang dalam beton bertulang disamping berfungsi sebagai tulangan pemikul gaya geser dan pengikat tulangan utama, namun juga berfungsi untuk meningkatkan daktilitas komponen struktur.

Analisis perilaku kolom beton bertulang mutu normal dengan pemasangan beberapa model dan jarak pengekangan yang diberi beban statis arah sentris kolom untuk mengetahui kemampuan kapasitas beban aksial ultimit, penyebaran distribusi dan konsentrasi tegangan (von mises), pola retak (creck) pada material beton serta daktilitas kolom

\section{Numerical Modeling}

Model kolom menggunakan kolom pendek persegi empat, diberikan pembebanan statis pada area penampang arah sentris kolom dibebani bertahap hingga kolom mengalami keruntuhan ultimit. Permodelan dengan system 3-D full-scale solid element dan link element. Stress dan strain beton yang digunakan menurut usulan Kent dan Park (1971) pada kondisi terkekang. Stress dan strain baja yang digunakan menurut usulan Park dan Paulay (1974)

\section{Kurva Tegangan - Regangan Beton Mutu Normal}

Kurva hubungan tegangan-regangan beton yang dikekang dengan sengkang usulan Kent dan Park seperti dalam Gambar 1 berikut:

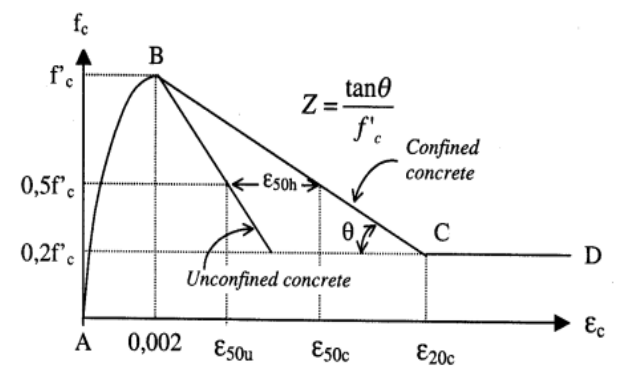

Gambar 1. Kurva hubungan tegangan-regangan beton yang dikekang dengan sengkang segi empat usulan kent dan Park (1971)

Kurva naik kurva turun dan kurva datar dengan persamaan-persamaan berikut:

Daerah $\mathrm{AB}: \varepsilon_{c} \leq 0,002$

$f_{c}=f_{c}^{\prime}\left[\frac{2 \varepsilon_{c}}{0,002}-\left(\frac{\varepsilon_{c}}{0,002}\right)^{2}\right]$

Daerah $\mathrm{BC}: 0,002 \leq \varepsilon_{c} \leq \varepsilon_{20 c}$

$f_{c}=f_{c}^{\prime}\left[1-Z\left(\varepsilon_{C}-0,002\right)\right]$

Daerah CD : $\varepsilon_{c} \geq \varepsilon_{20 c}$

$f_{c}=0,2 f_{c}^{\prime}$

Dimana:

$$
\begin{aligned}
& Z=\frac{0,5}{\varepsilon_{50 u}+\varepsilon_{50 h}-0,002} \\
& \varepsilon_{50 u}=\frac{3+0,002 f_{c}^{\prime}}{f_{c}^{\prime}-1000} \text { dan } \varepsilon_{50 h}=\frac{3}{4} \rho_{s} \sqrt{\frac{b^{\prime \prime}}{s_{h}}}
\end{aligned}
$$

$f_{c}^{\prime}$ adalah kuat tekan silinder beton dalam psi; $\rho_{s}$ adalah perbandingan volume tulangan melintang terhadap inti beton yang diukur terhadap bagian 
luar sengkang; $b^{\prime \prime}$ adalah lebar inti kekekangan diukur terhadap bagian luar sengkang; $s_{h}$ adalah jarak sengkang

\section{Kurva Tegangan - Regangan Baja Tulangan}

Dalam penelitiannya memuat Perhitungan untuk menentukan nilai tegangan dan regangan baja tulangan $\left(f_{s}-\varepsilon_{s}\right)$ menggunakan usulan Park dan Paulay (1974), seperti ditunjukkan pada Gambar 2 berikut:

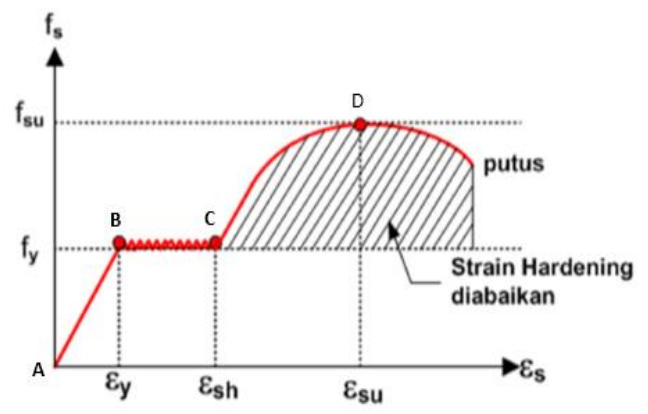

Gambar 2. Kurva hubungan tegangan-regangan baja tulangan usulan Park dan Paulay (1974)

Gambar 2 Diatas kurva tegangan-regangan setelah melewati titik leleh $\mathrm{C}$ baja mengalami regangan plastis cukup besar dengan tegangan yang hampir konstan yang disebut tegangan leleh $\left(f_{y}\right)$. Setelah melewati regangan batas leleh $\left(\varepsilon_{s h}\right)$, tegangan mulai naik lagi yaitu pada daerah $\mathrm{CD}$ yang menunjukkan pengaruh strain-hardening baja atau kondisi perkuatan regangan hingga mencapai tegangan maksimum $\left(f_{s u}\right)$ yang disebut dengan kuat tarik baja, dan akhirnya baja putus setelah mengalami penyempitan luas tampang (necking), dari kurva tersebut dapat dilihat karakteristikkarakteristik persamaan -persamaan berikut:

Daerah $\mathrm{AB}: \varepsilon_{s} \leq \varepsilon_{y}$

$f_{s}=\varepsilon_{s} E_{s}$

Daerah BC : $\varepsilon_{y} \leq \varepsilon_{s} \leq \varepsilon_{s h}$

$f_{s}=f_{y}$

Daerah $\mathrm{CD}: \varepsilon_{s h} \leq \varepsilon_{s} \leq \varepsilon_{s u}$

$f_{s}=f_{y}$

$\left[\frac{m\left(\varepsilon_{s}-\varepsilon_{s h}\right)+2}{60\left(\varepsilon_{s}-\varepsilon_{s h}\right)+2}+\frac{\left(\varepsilon_{s}-\varepsilon_{s h}\right)(60-m)}{2(30 r+1)^{2}}\right]$
Dimana:

$$
\begin{aligned}
& m=\frac{\left(f_{s u} / f_{y}\right)(30 r+1)^{2}-60 r-1}{15 r^{2}} \\
& r=\varepsilon_{s u}-\varepsilon_{s h}
\end{aligned}
$$

\section{Pengaruh Pengekangan (Confinement) Pada Kapasitas Tekan Kolom}

Pengekangan kolom memiliki tujuan utama untuk menghasilkan suatu elemen kolom yang lebih daktail, struktur yang daktail dibuat untuk meningkatkan ketahanan struktur terhadap gaya gempa yang cenderung bolak-balik, apabila gaya gempa mampu ditahan oleh kolom, maka keruntuhan mendadak suatu struktur dapat dicegah

Bousalem dan Chick (2007), telah melakukan studi terhadap pengekangan kolom beton untuk beban gempa, hasilnya menunjukkan bahwa pengekangan beton sangat berpengaruh terhadap ketahanan beban gempa.

Beberapa faktor penting dalam pengekangan kolom yaitu kekuatan/ mutu kolom, konfigurasi tulangan transversal, dan jumlah tulangan longitudinal. Sharif dkk (2010), meneliti pengaruh pengekangan terhadap kolom beton struktur pada pembebanan gempa dengan membandingkan beberapa pengekang kolom terkekang, hasilnya pengaruh ratio pengekangan dapat meningkatkan kapasitas daya dukung beban terhadap pengaruh gempa.

\section{Setting Analisis Program}

Analisis kolom beton bertulang pada program ANSYS dibuat dengan model tumpuan sendi-sendi, diberi beban aksial statis arah sentris kolom (vertikal). Loading plat dan plat landas dipasang pada tiap ujung kolom akan diberikan pembebanan tegangan (Pressure). Pembebanan dientri dalam 20 tahap (loadstep). 


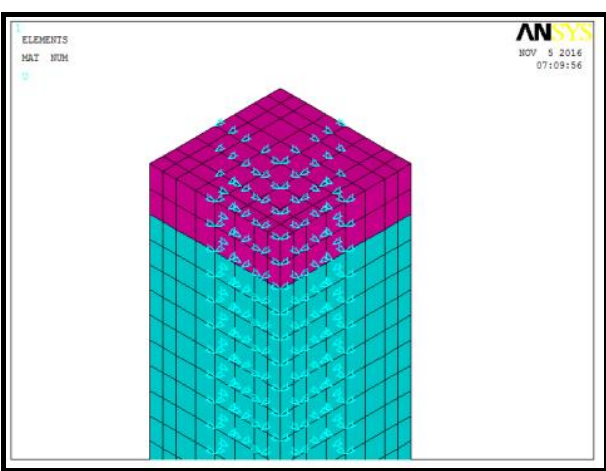

Gambar 3. Model tumpuan sendi-sendi beban statis arah sentris

\section{Jumlah dan Pengelompokan Model}

Dalam penelitian ini dimensi model kolom yang digunakan adalah ukuran 150x150x2100 mm. Tulangan utama $\varnothing 10 \mathrm{~mm}$ sebanyak 8 buah sedangkan, Untuk tulangan sengkang di area tumpuan $\varnothing 8 \mathrm{~mm}$ dan tulangan sengkang pada area lapangan $\varnothing 6 \mathrm{~mm}$.

Pengelompokan model berdasarkan variasi jarak yaitu masing-masing kelompok mewakili jarak $50 \mathrm{~mm}$, $100 \mathrm{~mm}, \quad 150 \mathrm{~mm}$ dan $200 \mathrm{~mm}$, adapun pengelompokan model pengekangan menggunakan analisis elemen hingga bantuan aplikasi ANSYS dengan berbagai variasi tersebut tercantum dalam Tabel 1. berikut:

Tabel 1. Pengelompokan model kolom. Mutu beton $f_{c}{ }^{\prime}=26,5 \mathrm{MPa}$. Tulangan Utama $f_{y} / f_{u}=360 / 520$ MPa. Tulangan Sengkang $f_{v} / f_{u}=240 / 350 \mathrm{MPa}$

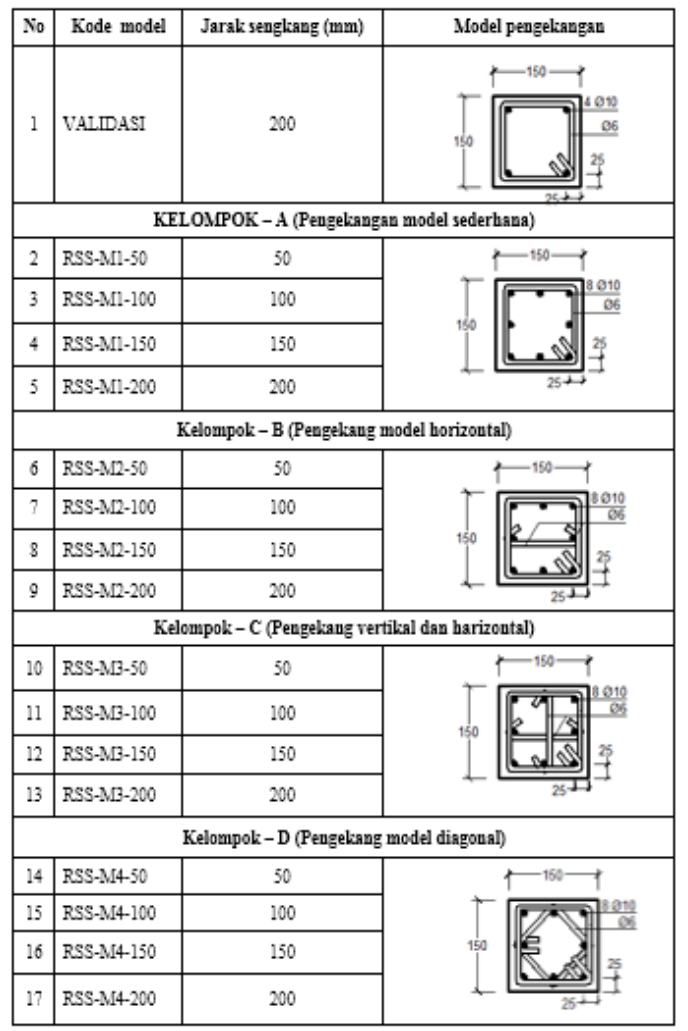

\section{Analisis Validasi dan Verifikasi Model}

Tujuan dari analisis validasi untuk memastikan hasil dari proses analisis aplikasi benar dan dapat diterima. Proses analisis modelmodel kolom akan mengacu pada analisis validasi sebagai standart serta parameter dalam tahapan menganalisis

Karateristik pembentuk kolom pada eksperimental yang dibuat di laboratorium berupa ukuran dimensi, mutu bahan, jenis tumpuan atau loading plat dan lainnya. Karakteristik dari model kolom validasi tersebut selanjutnya diolah pada aplikasi yaitu dengan tahapan pembuatan modeling, properties, mesh atribut, meshing dan lain sebagainya, dilanjutkan dengan melakukan analisis aplikasi dengan melakukan runing program.

Hasil analisis yang diperoleh dari aplikasi berupa nilai beban $(\mathrm{kN})$ dan nilai aksial deformasi $(\mathrm{mm})$. Selanjutnya nilai diplot kedalam grafik beban $(\mathrm{kN})$ vs aksial deformasi $(\mathrm{mm})$, grafik hasil dari analisis aplikasi dibandingkan dengan hasil analisis eksperimental dilaboratorium. Grafik hasil penelitian eksperimental dan hasil aplikasi ANSYS dapat dilihat pada Gambar 4 berikut:

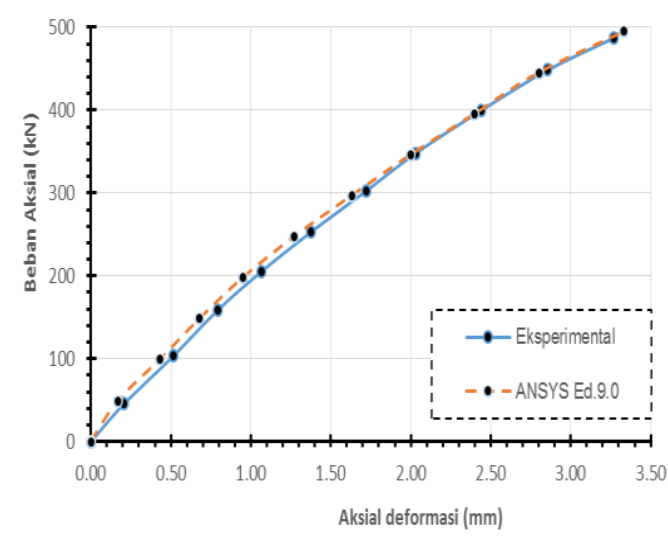


Gambar 4. Grafik perbandingan nilai Beban $(\mathrm{kN})$ vs Aksial deformasi (mm) antara penelitian ElKholy dan Dahish (2015) dengan hasil aplikasi ANSYS

Perbandingan antara nilai Beban aksial $(\mathrm{kN})$ vs Aksial deformasi $(\mathrm{mm})$ dari hasil analisis menggunakan aplikasi ANSYS dan hasil analisis eksperimental dilaboratorium relatif nilai sama. Nilai aksial deformasi hasil eksperimental diperoleh sebesar 3,27 mm, hasil Aplikasi ANSYS sebesar $3.33 \mathrm{~mm}$ dengan selisih perbedaan sebesar $1,83 \%$. nilai beban aksial ultimit hasil a. Pengaruh Jarak Pengekangan

Tabel 2. Nilai Beban Aksial Ultimit dan Deformasi Model Sederhana

\begin{tabular}{|c|l|c|c|c|c|c|c|}
\hline \multirow{2}{*}{ No } & \multirow{2}{*}{ Model } & \multicolumn{2}{|c|}{ Hasil Teoritis } & \multicolumn{2}{c|}{ Hasil ANSYS } & \multicolumn{2}{|c|}{ Rasio } \\
\cline { 3 - 8 } & & $\begin{array}{c}\mathrm{P}_{\mathrm{v}} \\
\mathbf{( k N})\end{array}$ & $\begin{array}{c}\Delta \mathrm{v} \\
(\mathbf{m m})\end{array}$ & $\begin{array}{c}\mathrm{P}_{\mathrm{v}} \\
\mathbf{( k N )}\end{array}$ & $\begin{array}{c}\Delta \mathrm{v} \\
(\mathbf{m m})\end{array}$ & $\mathrm{P}_{\mathrm{u}}$ & $\Delta_{\mathrm{v}}$ \\
\hline \hline 1 & RSS-M1-50 & 575,151 & 5,236 & 537,27 & 5,203 & 0,934 & 0,993 \\
\hline 2 & RSS-M1-100 & 575,151 & 5,236 & 540,05 & 4,701 & 0,938 & 0,897 \\
\hline 3 & RSS-M1-150 & 575,151 & 5,236 & 537,75 & 4,935 & 0,934 & 0,942 \\
\hline 4 & RSS-M1-200 & 575,151 & 5,236 & 539,99 & 3,670 & 0,938 & 0,700 \\
\hline
\end{tabular}

Tabel 4. Nilai Beban Aksial Ultimit dan Deformasi Model Vertikal dan Horizontal

\begin{tabular}{|c|c|c|c|c|c|c|c|}
\hline \multirow{2}{*}{ No } & \multirow{2}{*}{ Model } & \multicolumn{2}{|c|}{ Hasil Teoritis } & \multicolumn{2}{|c|}{ Hasil ANSYS } & \multicolumn{2}{|c|}{ Rasio } \\
\cline { 3 - 8 } & & $\begin{array}{c}\mathbf{P}_{\mathrm{v}} \\
\mathbf{( k N )}\end{array}$ & $\begin{array}{c}\Delta \mathrm{v} \\
(\mathbf{m m})\end{array}$ & $\begin{array}{c}\mathbf{P}_{\mathrm{v}} \\
\mathbf{( k N )}\end{array}$ & $\begin{array}{c}\Delta \mathrm{U} \\
\mathbf{( m m})\end{array}$ & $\mathbf{P}_{\mathrm{u}}$ & $\Delta \mathrm{v}$ \\
\hline \hline 1 & RSS-M3-50 & 575,151 & 5,236 & 559,13 & 5,493 & 0,972 & 1,049 \\
\hline 2 & RSS-M3-100 & 575,151 & 5,236 & 535,05 & 5,240 & 0,930 & 1,000 \\
\hline 3 & RSS-M3-150 & 575,151 & 5,236 & 536,92 & 4,387 & 0,933 & 0,837 \\
\hline 4 & RSS-M3-200 & 575,151 & 5,236 & 536,35 & 4,453 & 0,932 & 0,850 \\
\hline
\end{tabular}

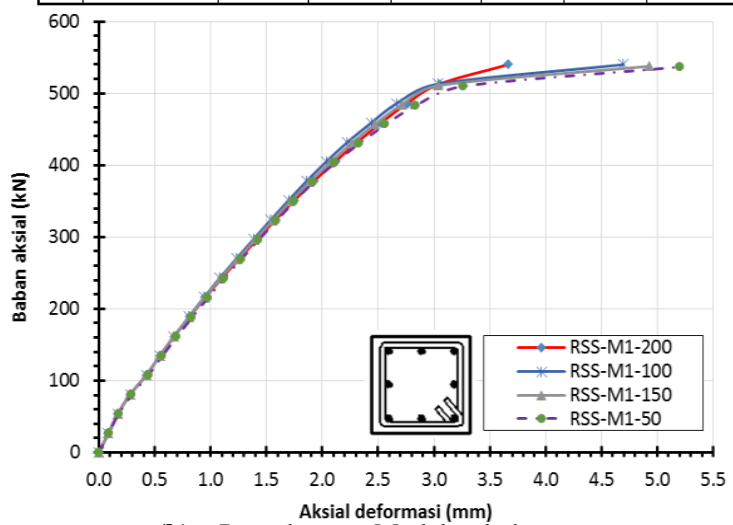

(b) Pengekangan Model sederhana

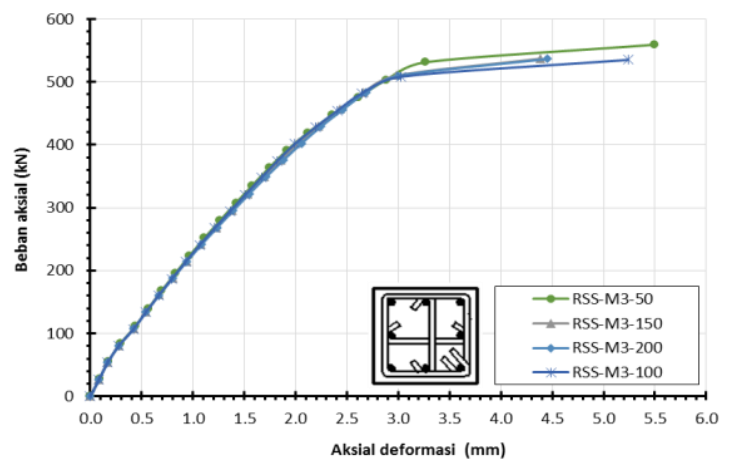

eksperimental dilaboratorium sebesar 486,98 kN. Hasil yang diperoleh aplikasi ANSYS beban aksial ultimit sebesar 495,00 $\mathrm{kN}$ dengan selisih perbedaan sebesar $1,64 \%$.

\section{Analisis Beban dan Deformasi Aksial Ultimit}

Perhitungan beban aksial terhadap deformasi dihitung secara teoritis dan dilakukan perbandingan dari hasil perhitungan program aplikasi ANSYS. Perhitungan beban aksial tersebut dihitung pada model yang akan dianalisis dan model validasi

Tabel 3. Nilai Beban Aksial Ultimit dan Deformasi Model Horizontal

\begin{tabular}{|c|c|c|c|c|c|c|c|}
\hline \multirow{2}{*}{ No } & \multirow{2}{*}{ Model } & \multicolumn{2}{|c|}{ Hasil Teoritis } & \multicolumn{2}{|c|}{ Hasil ANSYS } & \multicolumn{2}{|c|}{ Rasio } \\
\cline { 3 - 8 } & & $\begin{array}{c}\mathrm{P}_{\mathrm{v}} \\
\mathbf{( k V})\end{array}$ & $\begin{array}{c}\Delta \mathrm{v} \\
(\mathbf{m m})\end{array}$ & $\begin{array}{c}\mathrm{P}_{\mathrm{v}} \\
\mathbf{( k N})\end{array}$ & $\begin{array}{c}\Delta \mathrm{v} \\
(\mathbf{m m})\end{array}$ & $\mathrm{P}_{\mathrm{u}}$ & $\Delta_{\mathrm{U}}$ \\
\hline \hline 1 & RSS-M2-50 & 575,151 & 5,236 & 563,04 & 5,338 & 0,978 & 1,019 \\
\hline 2 & RSS-M2-100 & 575,151 & 5,236 & 538,90 & 5,097 & 0,936 & 0,978 \\
\hline 3 & RSS-M2-150 & 575,151 & 5,236 & 536,21 & 4,435 & 0,932 & 0,847 \\
\hline 4 & RSS-M2-200 & 575,151 & 5,236 & 536,63 & 3,882 & 0,933 & 0,741 \\
\hline
\end{tabular}

Tabel 5. Nilai Beban Aksial Ultimit dan Deformasi

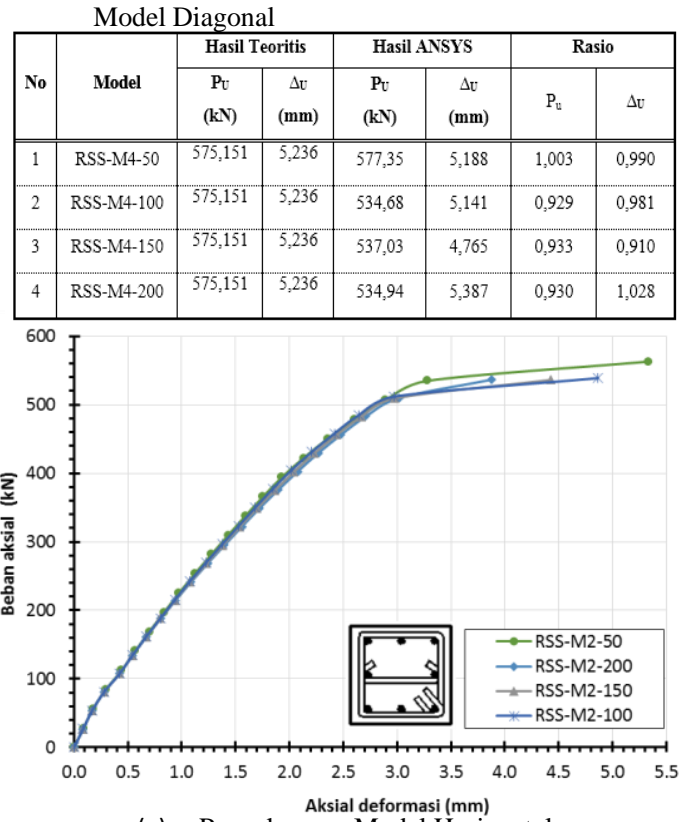

(a) Pengekangan Model Horizontal

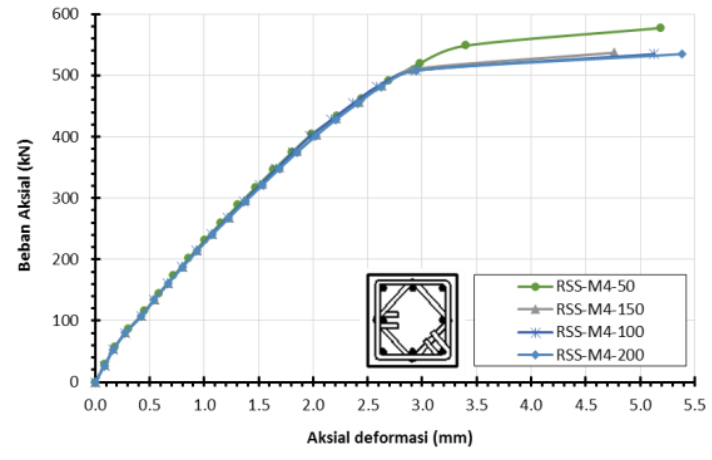

Media Ilmiah Teknik Sipil, Volume 8, Nomor 2, Juni 2020: 104-115 
Permodelan Pengekangan Kolom..., Ridho Saleh Silaban ${ }^{(1)}$, Darmansyah Tjitradi ${ }^{(2)}$, Syahril Taufik ${ }^{(3)}$

(d) Pengekangan Model Vertikal dan Horizontal

Gambar 5. Kurva hubungan Beban Aksial $(\mathrm{kN})$ vs Aksial Deformasi (mm) pengaruh jenis dan jarak pengekangan

\section{b. Pengaruh Model Pengekangan}

Tabel 6. Nilai Beban Aksial Ultimit dan Deformasi Pengekangan $50 \mathrm{~mm}$

\begin{tabular}{|c|c|c|c|c|c|c|c|}
\hline \multirow[t]{2}{*}{ No } & \multirow[t]{2}{*}{ Model } & \multirow{2}{*}{$\begin{array}{c}\text { Panjang } \\
\text { Sengkang } \\
(\mathrm{mm})\end{array}$} & \multirow{2}{*}{$\begin{array}{c}\text { Rasio } \\
\text { Sengkang } \\
(\%)\end{array}$} & \multirow{2}{*}{$\begin{array}{c}\mathrm{P}_{\mathrm{u}} \\
(\mathrm{kN})\end{array}$} & \multirow{2}{*}{$\begin{array}{c}\Delta \mathrm{v} \\
(\mathrm{mm})\end{array}$} & \multicolumn{2}{|c|}{$\begin{array}{c}\text { Rasio Terhadap Nilai } \\
\text { Terkecil. }\end{array}$} \\
\hline & & & & & & $P_{n}$ & $\Delta \mathrm{v}$ \\
\hline 1 & RSS-M1-50 & 513,85 & 4,37 & 537,27 & 5,203 & 1,000 & 1,002 \\
\hline 2 & RSS-M2-50 & 688,85 & 5,463 & 563,04 & 5,338 & 1,047 & 1,028 \\
\hline 3 & RSS-M3-50 & 863,85 & 6,556 & 559,13 & 5,493 & 1,040 & 1,058 \\
\hline 4 & RSS-M4-50 & 923,85 & 7,744 & 577,35 & 5,188 & 1,074 & 1,000 \\
\hline
\end{tabular}

Tabel 8. Nilai Beban Aksial Ultimit dan Deformasi

\begin{tabular}{|c|c|c|c|c|c|c|c|}
\hline & & eK & $\operatorname{san} 15$ & $\mathrm{~nm}$ & & & \\
\hline \multirow[t]{2}{*}{ No } & \multirow[t]{2}{*}{ Model } & \multirow{2}{*}{$\begin{array}{c}\text { Panjang } \\
\text { Sengkang } \\
(\mathrm{mm})\end{array}$} & \multirow{2}{*}{$\begin{array}{c}\text { Rasio } \\
\text { Sengkang } \\
(\%)\end{array}$} & \multirow{2}{*}{$\begin{array}{c}\mathbf{P}_{\mathrm{u}} \\
(\mathrm{kN})\end{array}$} & \multirow{2}{*}{$\begin{array}{c}\Delta_{\mathrm{U}} \\
(\mathrm{mm})\end{array}$} & \multicolumn{2}{|c|}{$\begin{array}{l}\text { Rasio Terhadap } \\
\text { Nilai Minimum. }\end{array}$} \\
\hline & & & & & & $\mathrm{Pu}_{\mathrm{u}}$ & $\Delta \mathrm{v}$ \\
\hline 1 & RSS-M1-150 & 513,85 & 1,457 & 537,75 & 4,939 & 1,002 & 1,125 \\
\hline 2 & RSS-M2-150 & 688,85 & 1,821 & 536,21 & 4,435 & 1,000 & 1,010 \\
\hline 3 & RSS-M3-150 & 863,85 & 2,185 & 536,92 & 4,387 & 1,001 & 1,000 \\
\hline 4 & RSS-M4-150 & 923,85 & 2,581 & 537,03 & 4,765 & 1,001 & 1,086 \\
\hline
\end{tabular}

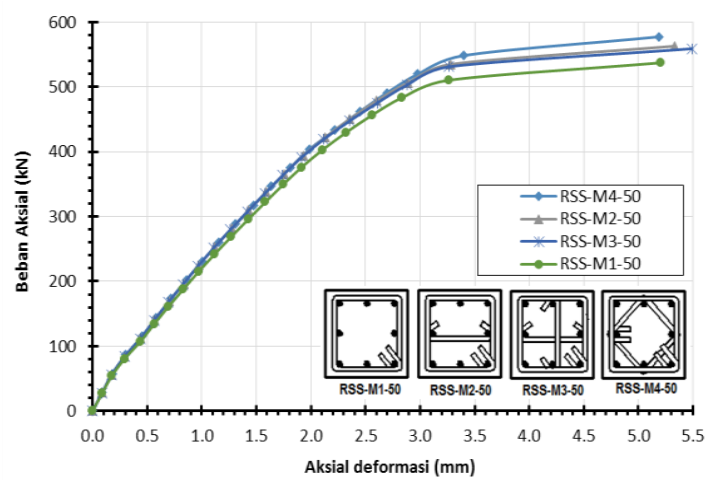

a) Jarak̉ Pengek̉angan $50 \mathrm{~mm}$

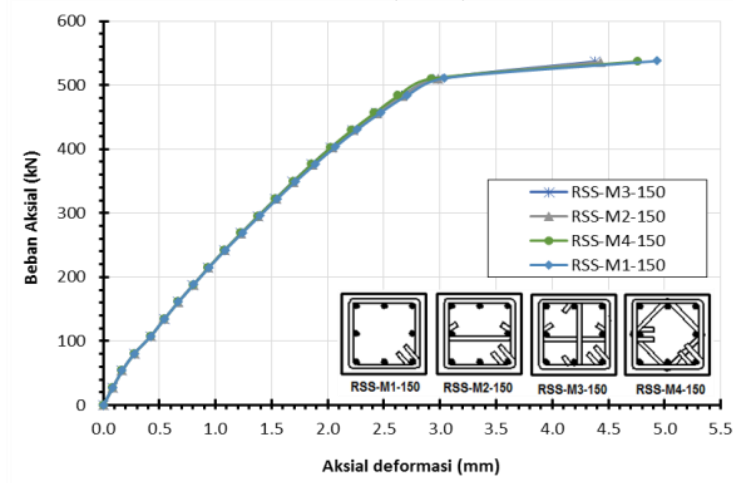

(c) Jarak pengekangan $150 \mathrm{~mm}$
Tabel 7. Nilai Beban Aksial Ultimit dan Deformasi Pengekangan $100 \mathrm{~mm}$

\begin{tabular}{|c|c|c|c|c|c|c|c|}
\hline \multirow[t]{2}{*}{ No } & \multirow[t]{2}{*}{ Model } & \multirow{2}{*}{$\begin{array}{c}\text { Panjang } \\
\text { Sengkang } \\
(\mathrm{mm})\end{array}$} & \multirow{2}{*}{$\begin{array}{c}\text { Rasio } \\
\text { Sengkang } \\
(\%)\end{array}$} & \multirow{2}{*}{$\begin{array}{c}\mathrm{P}_{\mathrm{a}} \\
(\mathrm{kN})\end{array}$} & \multirow{2}{*}{$\begin{array}{c}\Delta_{\mathrm{v}} \\
(\mathrm{mm})\end{array}$} & \multicolumn{2}{|c|}{$\begin{array}{c}\text { Rasio Terhadap } \\
\text { Nilai Terkecil }\end{array}$} \\
\hline & & & & & & $P_{u}$ & $\Delta \mathrm{v}$ \\
\hline 1 & RSS-M1-100 & 513,85 & 2,185 & 540,05 & 4,701 & 1,010 & 1,000 \\
\hline 2 & RSS-M2-100 & 688,85 & 2,731 & 538,90 & 5,097 & 1,007 & 1,084 \\
\hline 3 & RSS-MB-100 & 863,85 & 3,278 & 535,05 & 5,240 & 1,000 & 1,114 \\
\hline 4 & RSS-M4-100 & 923,85 & 3,872 & 534,68 & 5,141 & 1,000 & 1,093 \\
\hline
\end{tabular}

Tabel 9. Nilai Beban Aksial Ultimit dan Deformasi Pengekangan $200 \mathrm{~mm}$

\begin{tabular}{|c|c|c|c|c|c|c|c|}
\hline \multirow[t]{2}{*}{ No } & \multirow[t]{2}{*}{ Model } & \multirow{2}{*}{$\begin{array}{c}\text { Panjang } \\
\text { Sengkang } \\
(\mathrm{mm})\end{array}$} & \multirow{2}{*}{$\begin{array}{c}\text { Rasio } \\
\text { Sengkang } \\
(\%)\end{array}$} & \multirow{2}{*}{$\begin{array}{c}\mathbf{P}_{\mathbf{n}} \\
(\mathrm{kN})\end{array}$} & \multirow{2}{*}{$\begin{array}{c}\Delta_{\mathrm{U}} \\
(\mathrm{mm})\end{array}$} & \multicolumn{2}{|c|}{$\begin{array}{l}\text { Rasio Terhadap } \\
\text { Nilai Minimum. }\end{array}$} \\
\hline & & & & & & $P_{u}$ & $\Delta \mathrm{v}$ \\
\hline 1 & RSS-M1-200 & 513,85 & 1,092 & 539,99 & 3,670 & 1,009 & 1,000 \\
\hline 2 & RSS-M2-200 & 688,85 & 1,365 & 536,63 & 3,882 & 1,003 & 1,057 \\
\hline 3 & RSS-M3-200 & 863,85 & 1,639 & 536,35 & 4,453 & 1,002 & 1,213 \\
\hline 4 & RSS-M4-200 & 923,85 & 1,936 & 534,94 & 5,387 & 1,000 & 1,467 \\
\hline
\end{tabular}

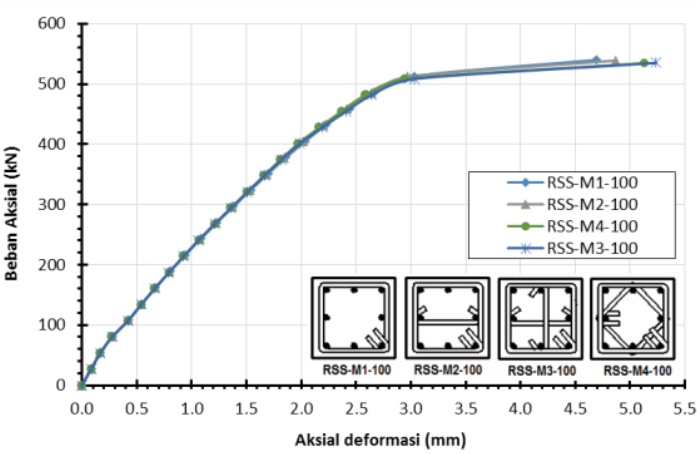

(b) Jarak Pengekangan $100 \mathrm{~mm}$

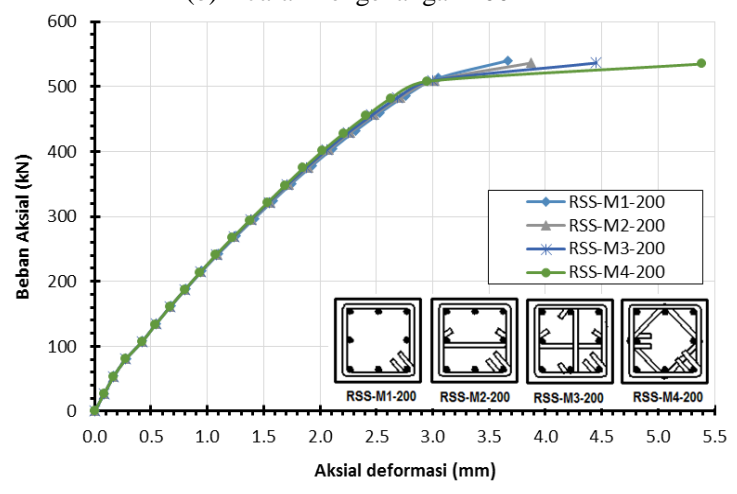

(d) Jarak pengekangan $200 \mathrm{~mm}$

Gambar 6. Kurva hubungan Beban Aksial $(\mathrm{kN})$ vs Aksial Deformasi $(\mathrm{mm})$ pengaruh model pengekangan dan variasi Jarak 


\section{Analisis Daktilitas Akibat Pengaruh Pengekangan}

Nilai daktilitas displacement dianalisis dari data hasil ANSYS, nilai ratio diperoleh dari hasil pembagian nilai deformasi beban ultimit $\left(\Delta_{\mathrm{u}}\right)$ dengan nilai deformasi yielding $\left(\Delta_{\mathrm{y}}\right)$. Untuk nilai deformasi pada saat kondisi yielding $\left(\Delta_{\mathrm{y}}\right)$ dari grafik deformasi vs tegangan dimana nilai deformasi saat kondisi yielding $\left(\Delta_{\mathrm{y}}\right)$ adalah nilai deformasi saat tegangan $(\sigma y)$ telah mencapai nilai $0.7 \cdot \sqrt{f c^{\prime}}$

Konfigurasi nilai daktilitas akibat pengaruh model pengekangan dan pengaruh jarak pengekangan untuk semua model dapat dilihat pada diagram batang pada Gambar 9 dan Gambar 10

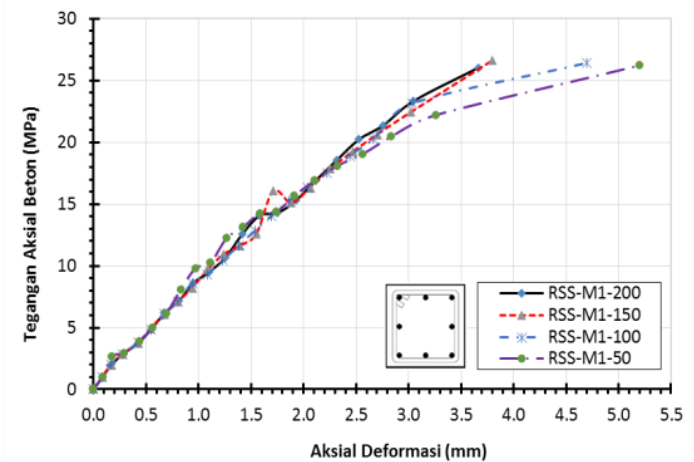

(a) Pengekangan Model Horizontal

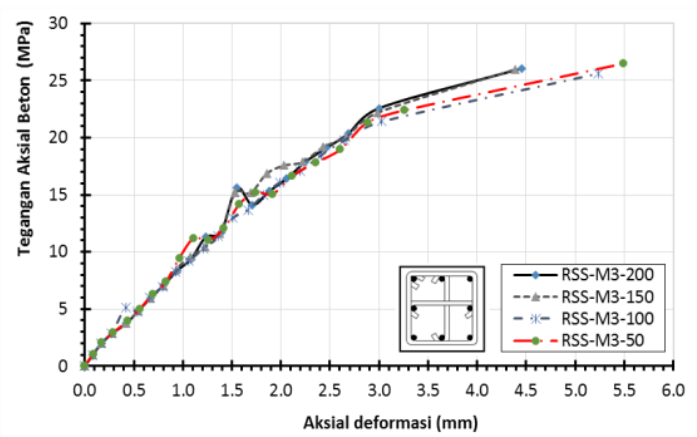

(c) Pengekangan Model Vertikal dan Horizontal

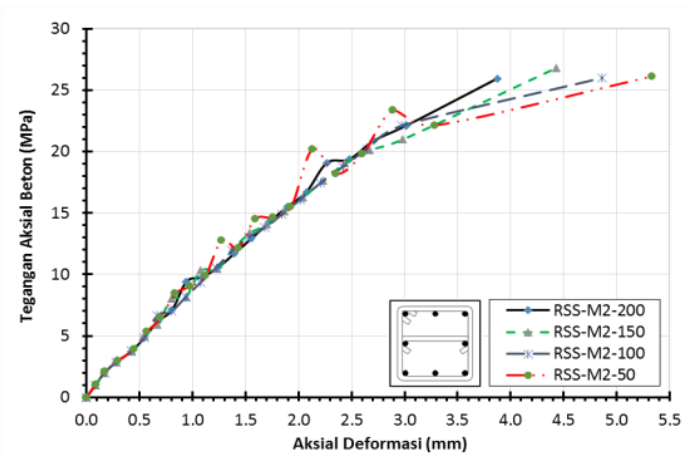

(b) Pengekangan Model Horizontal

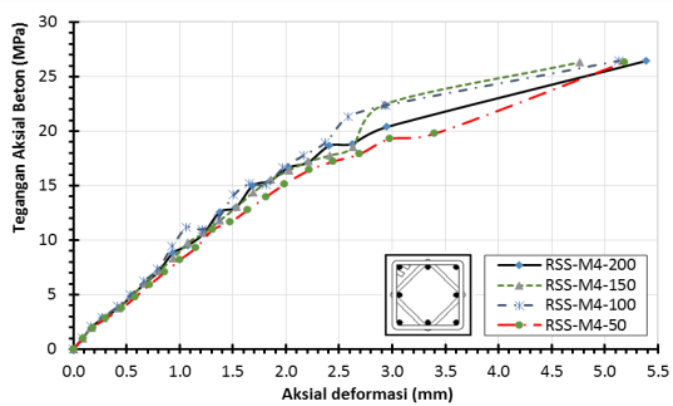

(d) Pengekangan Model Diagonal

Gambar 7. Kurva hubungan tegangan (MPa) vs aksial deformasi (mm)

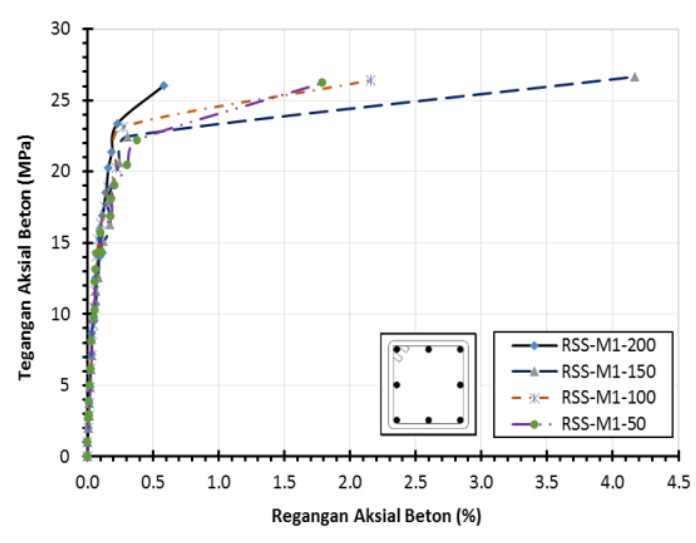

(a) Pengekangan Model Horizontal

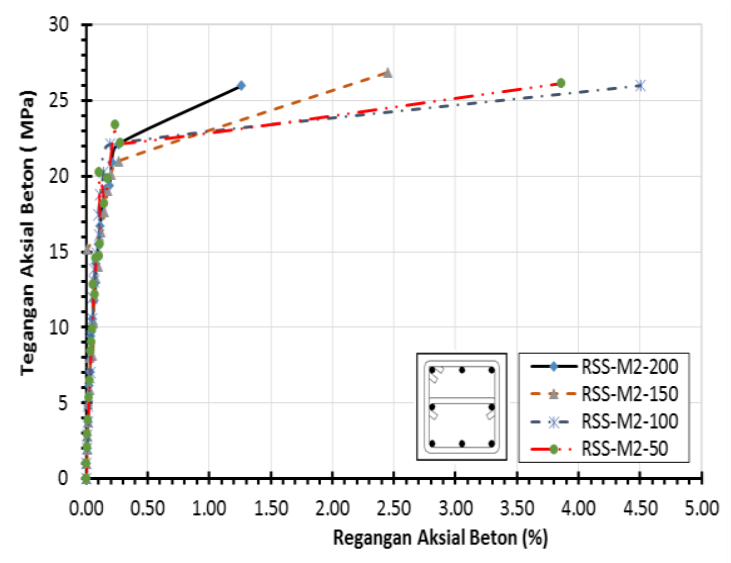

(b) Pengekangan Model Horizontal 


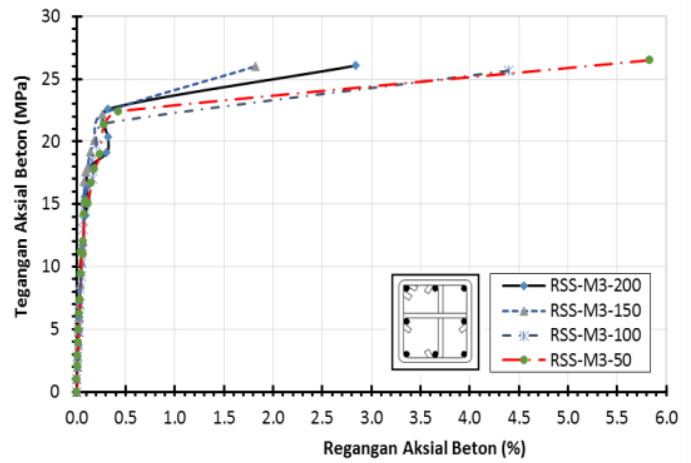

(c) Pengekangan Model Vertikal dan Horizontal

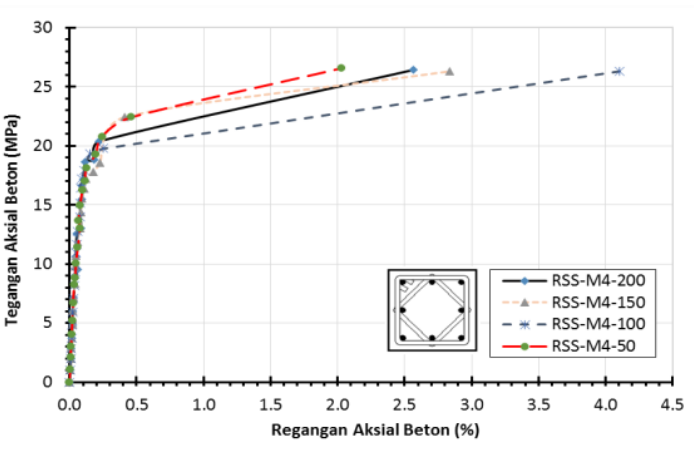

(d) Pengekangan Model Diagonal

Gambar 8. Kurva hubungan tegangan (MPa) vs regangan

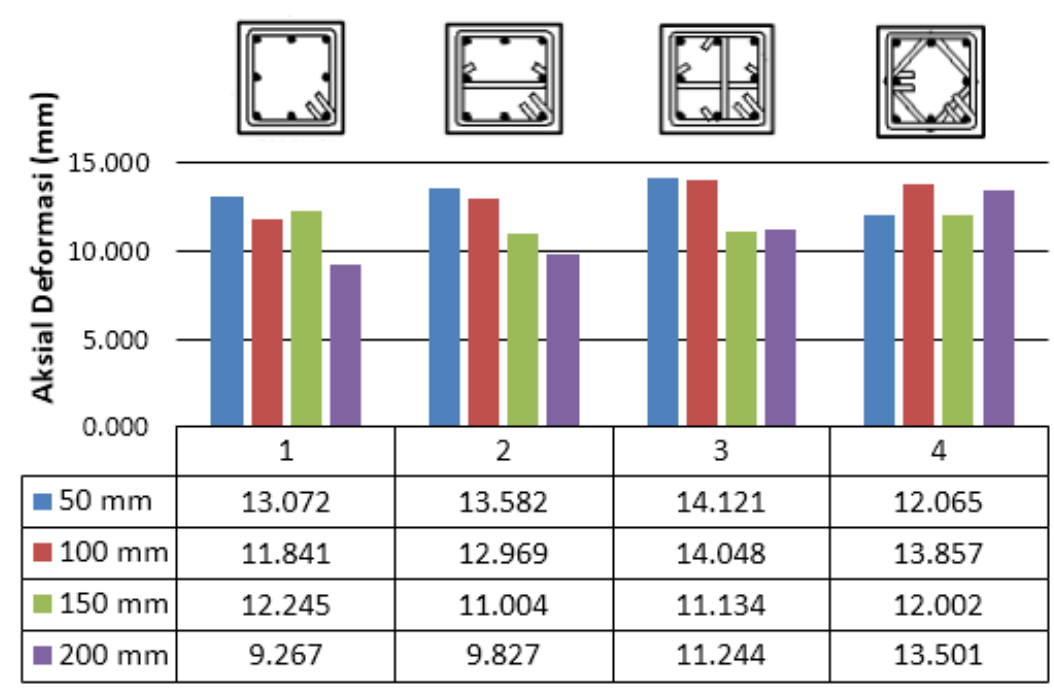

Gambar 9. Diagram nilai daktilitas akibat pengaruh model pengekangan

Dari Gambar 9 diatas terlihat jarak pengekangan memberikan pengaruh terhadap nilai daktilitas. Pada pengekangan model sederhana, model horizontal serta model vertikal dan horizontal dominanan jarak pengekangan yang lebih rapat akan memberikan nilai daktilitas yang lebih tinggi dibandingkan jarak pengekangan yang lebih renggang. Namun untuk model diagonal pengaruh pemberian jarak pengekangan relatif belum efektif untuk meningkatkan nilai daktilitas

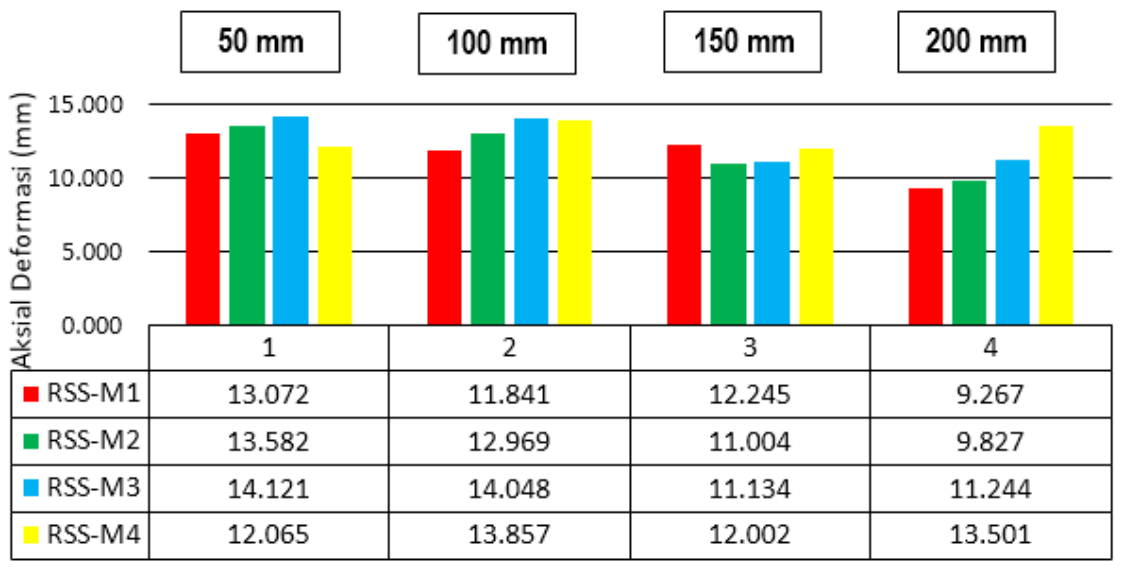

Gambar 10. Diagram nilai daktilitas akibat pengaruh jarak pengekangan 
Dari Gambar 10 terlihat rasio tulangan sengkang $\left(\rho_{\mathrm{s}}\right)$ memberikan pengaruh terhadap nilai daktilitas. Semakin besar nilai rasio tulangan sengkang $\left(\rho_{\mathrm{s}}\right)$ maka akan semakin tinggi nilai daktilitasnya. Rasio tulangan sengkang $\left(\rho_{\mathrm{s}}\right)$ sangat efektif meningkatkan nilai daktilitas pada pengekang yang lebih renggang terlihat pada jarak pengekangan $200 \mathrm{~mm}$ nilai daktilitasnya terus meningkat

\section{HASIL DAN PEMBAHASAN}

Berdasarkan analisis matematik dan analisis bantuan aplikasi ANSYS dapat diambil beberapa kesimpulan sebagai berikut:

1. Kemampuan beban aksial ultimit dan aksial deformasi akibat pengaruh pengekangan

a. Pengaruh model pengekang terhadap nilai beban aksial ultimit relatif kecil, diperoleh rasio perbandingan nilai beban aksial ultimit terbesar dengan nilai beban aksial terkecil untuk semua model pengekang dan jarak pengekangan hanya 1,079 atau selisih nilainya sebesar $7,98 \%$ dengan nilai beban aksial ultimit terbesar pada pengekangan model Diagonal jarak pengekangan $50 \mathrm{~mm}$ yaitu sebesar 577,350 kN, sedangkan untuk nilai beban aksial ultimit terkecil pada pengekangan model Diagonal jarak pengekangan $100 \mathrm{~mm}$ yaitu sebesar 534,680 $\mathrm{kN}$

b. Pengaruh model pengekang terhadap nilai aksial deformasi memberikan pengaruh yang relatif cukup besar, diperoleh rasio perbandingan nilai aksial deformasi terbesar dengan nilai aksial deformasi terkecil untuk semua model pengekang dan jarak pengekangan sebesar 1,523 atau selisih nilainya sebesar 49,673\% dengan nilai aksial deformasi terbesar pada pengekangan model Verikal \& Horizontal jarak pengekangan 50 mm yaitu sebesar 5,493 mm, sedangkan untuk nilai aksial deformasi terkecil pada pengekangan model Sederhana jarak pengekangan $200 \mathrm{~mm}$ yaitu sebesar 3,670 $\mathrm{mm}$

2. Perilaku distribusi dan konsentrasi tegangan dan regangan (von mises) akibat pengaruh pengekangan

a. Pengaruh model penulangan dan variasi jarak pengekangan terhadap konsentrasi tegangan maksimum yang terjadi pada saat yielding atau retak pertama terdistribusi dengan merata pada seluruh kolom diarea tumpuan maupun diarea lapangan namun hanya terkonsentrasi pada lapisan selimut kolom

b. Pengaruh model penulangan dan variasi jarak pengekangan terhadap konsentrasi tegangan yang terjadi pada saat beban aksial ultimit bekerja, dari seluruh model pengekangan dan variasi jarak pengekangan dominasi tegangan terkonsentrasi pada area tumpuan dan tersebar pada lapisan kolom

c. Pengaruh model penulangan dan variasi jarak pengekangan terhadap konsentrasi regangan pada saat terjadi beban aksial ultimit bekerja, dari seluruh model pengekangan dan variasi jarak pengekangan dominan terkonsentrasi pada area tumpuan baik diarea tumpuan atas maupun diarea tumpuan bawah namun ada beberapa model terjadi pada area lapangan

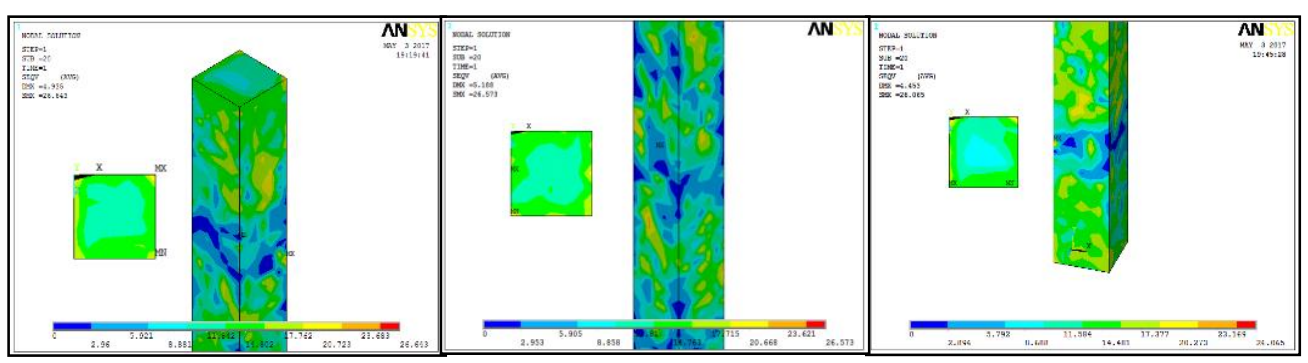

Gambar 11. Konsentrasi tegangan saat ultimit 


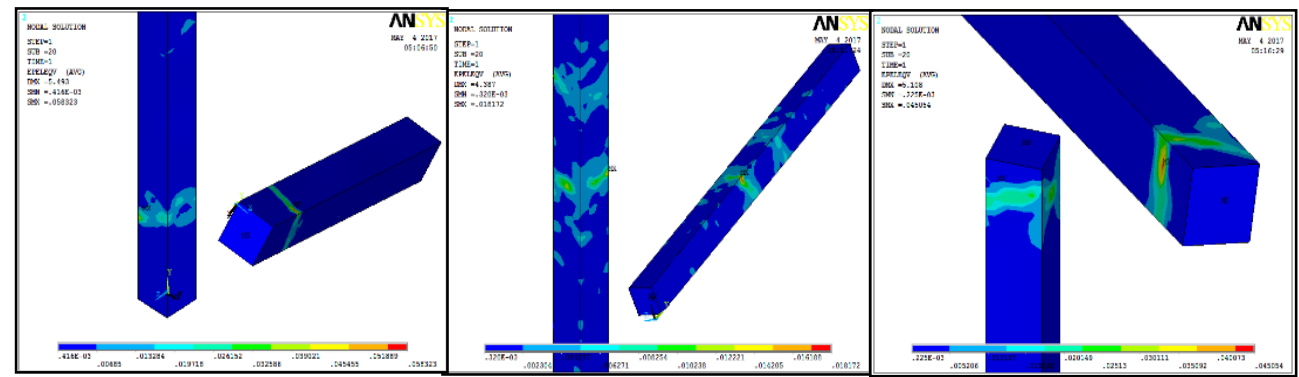

Gambar 12. Konsentrasi regangan saat ultimit

3. Perilaku pola retak (crack) pada material beton pada kolom

a. Retak pertama didominasi terjadi pada lapisan selimut beton dan pada umumnya dimulai pada area tumpuan, seiring meningkatnya beban aksial maka retakan juga semakin bertambah besar menuju area lapangan kolom dan memasuki lapisan inti kolom. Terkecuali untuk pengekangan model Diagonal dominan retakan awal terjadi pada lapisan inti kolom tepatnya pada celah-celah antara tulangan sengkang berbentuk persegi dan tulangan berbentuk diagonal atau pada posisi bengkokan pada tulangan Diagonal, hal ini diperkirakan pengaruh dari terlalu kecilnya ruang yang tersedia untuk penempatan bahan spesimen beton menyebabkan pada ruang ini volume penempatan dari spesiment beton kecil sehingga mempermudah terjadinya retakan, seiring meningkatnya beban maka retakan yang awalnya hanya pada inti kolom berlanjut pada lapisan selimut kolom dan terus bertambah besar hingga menyebar keseluruh area kolom

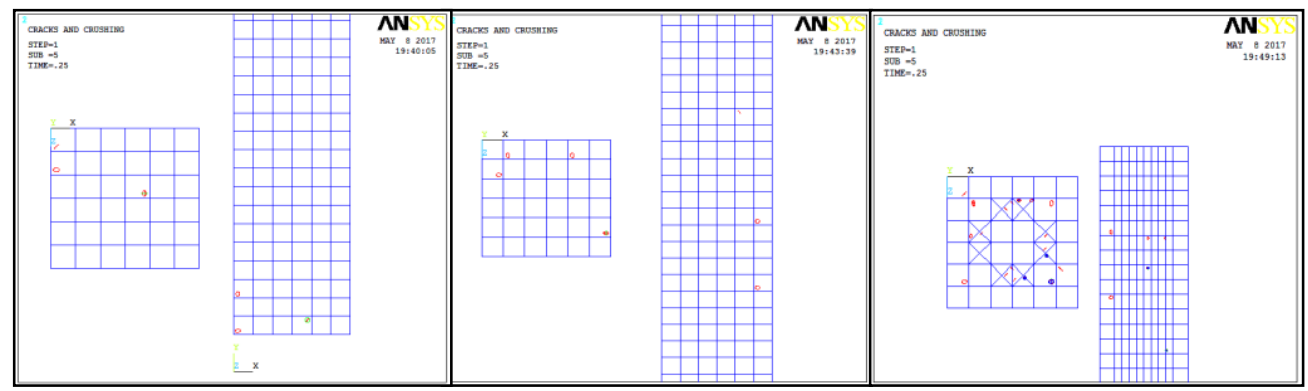

Gambar 13. Kondisi retak pertama pada area tumpuan bawah terkonsentrasi dilapisan selimut kolom

b. Pada saat mencapai beban aksial ultimit maka sebagian besar bahan beton mengalami retak bahkan terlihat retakan pada seluruh area kolom dari area tumpuan hingga area lapangan, retakan juga terjadi pada lapisan selimut beton maupun inti kolom

4. Daktilitas akibat pengaruh pengekangan

a. Pengekangan model vertikal dan horizontal dengan jarak pengekangan $50 \mathrm{~mm}$ memperoleh nilai ratio daktilitas tertinggi yaitu sebesar 14.121, dengan jarak $75 \mathrm{~mm}$ didapatkan nilai daktilitas sebesar 14,9605 untuk menghidari jarak sengkang yang terlalu rapat untuk agregat ukuran besar bisa lolos b. Semakin tinggi ratio tulangan geser maka ( $\rho)$ maka nilai daktilitas akan semakin meningkat

c. Pemberian jarak pengekangan pada kolom memberikan pengaruh yang cukup besar terhadap nilai daktilitas, dimana ratio perbandingan nilai daktilitas terhadap jarak pengekangan untuk model pengekangan sederhana sebesar 1,410. Pengekangan model horizontal sebesar 1,382. Pengekangan model vertikal dan horizontal sebesar 1,255 dan Pengekangan model diagonal sebesar 0,893

d. Berdasarkan kurva hubungan antara jarak pengekangan (s) dan daktilitas $(\mu)$, maka dapat dibuat persamaan kurva fitting seperti 
e. pada Lampiran D maka diperoleh persamaan sebagai berikut:

- Persamaan kurva fitting hubungan antara Jarak pengekangan (s) dan

- Daktilitas ( $\mu$ ) untuk model sederhana adalah:

$\mu=-7 \mathrm{E}-06 \mathrm{~s}^{3}+0,0023 \mathrm{~s}^{2}-0,2576 \mathrm{~s}+20,955$

- Persamaan kurva fitting hubungan antara Jarak pengekangan (s) dan Daktilitas $(\mu)$ untuk model horizontal adalah:

$\mu=3 E-06 s^{3}-0,0011 s^{2}+0,1068 s+10.703$

- Persamaan kurva fitting hubungan antara Jarak pengekangan (s) dan Daktilitas $(\mu)$ untuk model vertikal dan horizontal adalah: $\mu=8 \mathrm{E}-06 \mathrm{~s}^{3}+0,0029 \mathrm{~s}^{2}+-0,2988 \mathrm{~s}+5,488$

- Persamaan kurva fitting hubungan antara Jarak pengekangan (s) dan Daktilitas $(\mu)$ Untuk model diagonal adalah: $\mu=0,018 s^{3}-5,3985 s^{2}+494,94 s+13488$

\section{PENUTUP}

\section{Kesimpulan}

Berdasarkan analisis model menggunakan perhitungan manual dan analisis model metode Finite Element Analisis (FEA) dengan bantual aplikasi komputer ANSYS pada kolom dengan beberapa model pengekangan dan variasi jarak pengekangan, dapat diambil kesimpulkan sebagai berikut:

1. Pemberian model dan variasi jarak pengekangan pada kolom memberikan pengaruh relatif kecil terhadap peningkatan nilai beban aksial ultimit. Rasio selisih antara nilai beban aksial tertinggi dan terkecil untuk semua model hanya sebesar 1,079 atau selisih nilainya sebesar $7,98 \%$. Rasio tulangan sengkang memberikan pengaruh terhadap nilai deformasi, meningkatnya nilai rasio tulangan maka akan meningkatkan nilai kemampuan kolom untuk berdeformasi. Rasio perbandingan nilai aksial deformasi terbesar dengan nilai aksial deformasi terkecil untuk semua model pengekang dan jarak pengekangan sebesar 1,523 atau selisih nilainya sebesar $49,673 \%$

2. Pola distribusi tegangan dan regangan yang terjadi pada saat retak pertama merata pada seluruh area kolom dari area tumpuan hingga area lapangan. Namun pada saat mencapai kondisi ultimit pola tegangan dan regangan terkonsentrasi pada area tumpuan.

3. Retak pertama didominasi terjadi pada lapisan selimut beton dan pada umumnya dimulai pada area tumpuan terkecuali untuk pengekangan model Diagonal retakan awal terjadi pada inti kolom. Seiring meningkatnya beban aksial maka retakan juga semakin bertambah besar menuju area lapangan kolom dan memasuki lapisan inti kolom. Pada saat mencapai beban aksial ultimit maka sebagian besar bahan beton mengalami retak bahkan terlihat retakan pada seluruh area kolom dari area tumpuan hingga area lapangan, retakan juga terjadi pada lapisan selimut beton maupun inti kolom.

4. Rasio tulangan sengkang mempengaruhi nilai daktilitas, meningkatkan nilai rasio tulangan sengkang pada kolom akan meningkatkan nilai daktilitas, pemberian jarak pengekangan yang lebih rapat akan memberikan nilai daktilitas cukup besar. ratio perbandingan nilai daktilitas terhadap jarak pengekangan untuk model pengekangan sederhana sebesar 1,410. Pengekangan model horizontal sebesar 1,382. Pengekangan model vertikal dan horizontal sebesar 1,255 dan Pengekangan model Diagonal sebesar 0,893

\section{Saran}

Berdasarkan hasil analisis yang diperoleh dalam penelitian ini, beberapa saran yang dapat diusulkan sebagai bahan dasar penelitian lanjutan, adalah sebagai berikut:

1. Dilakukan pengembangan model pengekangan yang lebih rumit

2. Menggunakan model stress dan strain beton bertulang modifikasi terbaru selain dari usulan Kent dan Park

3. Penggunaan variasi mutu beton sampai dengan $50 \mathrm{MPa}$

4. Dimensi kolom yang lebih langsing

5. Variasi perlakuan pembebanan dengan beban lateral

6. Perbandingan dengan kolom komposit vs kolom terkekang 


\section{DAFTAR PUSTAKA}

Eksana D., W., Triwiyono A., \& Siswosukarto S., 2012. Perkuatan geser kolom beton bertulang berpenampang persegi dengan kawat kasa metode mortar jacketing berpenampang bulat., Jurnal Inersia Vol.VIII No. Mei

El-Kholy A.M \& Danish H.A., 2015. Inproved confinement of reinforced concrete colums, Ain Shams Engineering Journal

Ibrahim S.I, 2012. Non Linear Finite Element Analysis of Confined HSC Columns Under Concentric and Eccentric Loadings, Journal of Engineering and Developmen, Vol. 16. No.3, September

Krisnamukti, Wiswamitra K.A., Kriswardana W., 2013. Pengaruh variasi bentuk penampang kolom terhadap perilaku elemen struktur akibat beban gempa, Jurnal Rekayasa Sipil, Vol. 7. No.1

Kristianto A., Imran I., \& Made S., 2011. Studi Eksperimental Penggunaan Tulangan Pengekang Tidak Standar yang Dimodifikasi pada kolom Persegi beton bertulang, Jurnal Teknik Sipil, Vol.18, No.3, Desember

Kritianto A., \& Yansusan I., 2015. Studi perkuatan kolom eksisting Dengan pen-binder untuk peningkatan daktilitas kolom beton bertulang, Jurnal teknik sipil Vol.10.No.1, April

Kristianto A., Imran I., Made S., Perilaku struktur kolom beton bertulang dengan Modifikasi pemasangan tulangan pengekang akibat Beban aksial dan lateral siklis, Jurnal Teknik Sipil

Parmo, 2014. Kekuatan dan daktilitas perpindahan Kolom pendek beton bertulang persegi dibawah pengaruh pembebanan siklik, Jurnal ilmu-ilmu teknik Vol.10. No.2

Park, R. 1988. State of the Art Report Ductility Evaluation from Laboratory and Analytical Testing, Proceeding of 9th World Conference on Earthquake Engineering, August 2-9, Tokyo-Kyoto, Japan.

Park, R. \& Paulay, T., 1974. Reinforced Concrete Structure, A Wiley-Interscience publication, John Wiley \& Sons
Karimah R., \& Wahyudi, 2010. Daktilitas kolom beton bertulang dengan pengekang didaerah sendi plastis, Jurnal teknik Industri, Vol.11. No.2, Agustus

Kamila A., Agoes SMD., \& Tavio 2012. Pengaruh Pengekangan GFRP terhadap kekuatan dan daktilitis kolom beton bertulang persegi akibat beban siklik, Jurnal media Teknik Sipil, Vol.10. No.2, Agustus

Sabirin B., Purwanto R., \& Priyosulistyo. 2004. Efek Pengekangan Kolom Berlubang Beton Mutu Normal Terhadap Daktilitas Kurvatur. Journal

Siregar Y.A.N., 2008. Evaluasi daktilitas pada struktur ganda, Penelitian Depertemen Sipil, Fak. Teknik UI

SNI 03-2847-2002., 2002. Tata cara perhitungan struktur beton untuk bangunan gedung, Badan Standardisasi Nasional, Jakarta

Sumirin, 2006. Kajian Kekuatan dan daktilitas Kolom bertulang, Jurnal Media komunikasi teknik sipil, Vol.14. No.1 Februari

Sharif M.B, M. Ilyas dan Baig M. M. A. S., 2010. Comparison of Confinement Reinforcement in Reinforced Concrete Structures, Pakistan Journal of Science, vol.62. No.1, Marc

Taufik S., 2008. Behavior of Boilted Connection With Higt Strenght and Stainless Steel. Ph.D, Theses University UK.

Teras D., 2013. Pengaruh tempratur terhadap perilaku dan kekuatan kolom terkekang, ULM. Tesis Magister Teknik Sipil

Tjitradi D., 2008. Modifikasi Kurva Tegangan Regangan Beton Kent Park (1971) Menjadi blok tegangan segi empat ekivalen, journal

Thorhallsson E.R., \& Bjarnason P.V, 2012. Test of Rectangular Confined Concrete Columns for Strength and Ductility, journal 15 WCEE LISBOA

Wibowo A., Hidayat M.T. \& Rohim A., Variasi rasio volume tulangan transversal dengan inti beton terhadap daktilitas aksial kolom beton bertulang, Jurnal Rekayasa Sipil, Vol.3. No.3 